\title{
OVARIAN GROWTH DURING LARVAL DEVELOPMENT OF QUEEN AND WORKER OF Apis mellifera (HYMENOPTERA: APIDAE): A MORPHOMETRIC AND HISTOLOGICAL STUDY
}

\author{
REGINATO, R. D. and CRUZ-LANDIM, C. \\ Departamento de Biologia, Instituto de Biociências de Rio Claro (UNESP), CEP 13506-900, Rio Claro, SP, Brazil \\ Correspondence to: Rejane Daniele Reginato, Departamento de Biologia, Instituto de Biociências de \\ Rio Claro (UNESP), CEP 13506-900, Rio Claro, SP, Brazil, e-mail: cclandim@ @r.unesp.br \\ Received September 21, 2001 - Accepted May 14, 2002 - Distributed February 28, 2003
}

(With 15 figures)

\begin{abstract}
The present work reports the differences between the ovarian grow in queen and worker larvae of A. mellifera, from the start of differential feeding. The observations made of the growth rates in larvae of both castes showed that the queen and worker larvae have the same rates of cephalic capsule growth from one instar to another but the weight gain is greater in queens. In the same way, the draw areas of ovaries of queens increase more and continuously, while from the $5^{\text {th }}$ instar on the ovaries of workers decrease in size. The decrease is due to a loss of ovariole numbers that starts early in the worker larvae and increases in the $4^{\text {th }}-5^{\text {th }}$ instar. The ovarian shape in queens and workers became different in the last larval instars.
\end{abstract}

Key words: honeybee, castes, differentiation, ovary, ovariole loss.

\section{RESUMO}

\section{Crescimento ovariano durante o desenvolvimento larval de operárias e rainhas de Apis mellifera (Hymenoptera: Apidae): estudos morfométricos e histológicos}

O presente trabalho relata as diferenças verificadas no desenvolvimento das larvas de rainhas e operárias e de seus ovários, desde o início da alimentação diferencial, dadas as duas castas, ou seja, desde o $3^{\text {o }}$ dia de desenvolvimento larval. As taxas de crescimento em ambas as castas mostram que as larvas de rainhas e de operárias apresentam o mesmo índice de crescimento da cápsula cefálica de um instar para outro, mas que o ganho de peso é muito maior nas rainhas. Da mesma forma, os ovários das rainhas crescem mais e continuamente, enquanto os das operárias decrescem a partir do $5^{\circ}$ instar. O decréscimo se deve à perda de ovaríolos que começa cedo na larva de operárias e aumenta nos $4^{\circ}$ e $5^{\circ}$ instares. A forma dos ovários das rainhas e das operárias já é diferente no último instar larval.

Palavras-chave: abelha melífera, castas, diferenciação, ovário, perda de ovaríolos.

\section{INTRODUCTION}

In the eusocial Apinae bees a division of the reproductive work in colonies convey to two female castes, one fertile (the queen) and another sterile or partially sterile (the worker). This condition is reflected in a marked dimorphism in ovarian development between queens and workers. In Apis mellifera, the dimorphism is expressed as different numbers of ovarioles per ovary in the castes
(Snodgrass, 1956). Each queen ovary contains more than 100-180 ovarioles, while in workers there are generally less than ten (Oertel, 1930; Snodgrass, 1956; Chaud-Netto \& Bueno, 1979; Morini \& Bueno, 1995). The difference in ovariole numbers, between worker and queen, results from the worker ovary atrophy during the larval development, consequence of the differential feeding of the castes (Zander \& Becker, 1925; Oertel, 1930; Lotmar, 1945; Kuwabara, 1947). 
The differences in the food received by queen and worker larvae of Apis mellifera are both qualitative and quantitative (Haydak, 1943; Ribbands, 1953) and start in the $2^{\text {nd }}$ or $3^{\text {rd }}$ day after hatching. During all larval phases the queen larvae are fed with royal jelly, while the worker larvae, once they are 2-3 days old, are fed with a blend of jelly, honey and pollen.

The ovaries, present in larvae at the hatching time, undergo, according to Anglas (1900), during the larval phase a process of development without histolosys or reabsorption. Actually, Meier (1916) counted 62-72 ovarioles in 2 day old worker larva and 74-89 ovarioles in 3 day old larva, however, the numbers reached by workers were not ever equal to that achieved by the queen larvae at the same age (Löschel, cited by Meier, 1916). It seems therefore, that the ovariole number in ovaries is different during the larval phase in workers and queens. However, several other studies demonstrate that the ovariolar numbers are the same in all early larvae and that the final differences between queen and worker are due to ovariole reabsorption in worker ovaries (Bueno, 1981; Hartfelder \& Steinbrück, 1997).

Another aspect to consider is the time when the differences between worker and queen are established, or when worker ovarioles start to suffer reabsorption. According to Bueno (1981) and Hartfelder \& Steinbrück (1997) reabsorption takes place by the end of the larval phase $\left(4^{\text {th }}, 5^{\text {th }}\right.$ instar $)$, but previous results indicate an early initiation of the process (Lotmar, 1945; Beetsma, 1979).

The papers on honeybee castes differentiation (Rembold, 1987; Rachinsky et al., 1990; Evans \& Wheeler, 1999) do not consider the subject of ovary development. Therefore, the present work attempts to contribute in solving this pendent question by analysing the size and histology of worker and queen ovaries during larval development.

\section{MATERIAL AND METHODS}

Two day old larvae were collected from the colony and grafted to queen cups containing royal jelly for queen artificial production. The remaining larvae of the same age and egg-laying queen were left in the comb to develop into workers. Larvae from queen cups and from worker brood cells were collected daily from one to six days after grafting. These larvae were weighed and the width of their cephalic capsules were measured at the level of the antennal imaginal discs in order to determine their developmental instar, by comparison with the previous data of Goitein (1989). Their ovaries were then excised, their contours outlined on paper with a camera lucida, and the relative areas of the drawings calculated. Some ovaries were fixed for light (LM) and scanning electron microscopy (SEM) studies, in $4 \%$ paraformaldehyde in $0,1 \mathrm{M}$ phosphate buffer, $\mathrm{pH}$ 7.4. For light microscopy, the ovaries were embedded in historesin and the sections stained with hematoxylin and eosin according to the usual procedures. The specimens used for SEM were dehydrated, dried at critical point and coated with gold.

\section{RESULTS}

The measurements of the larval cephalic capsula width (Fig. 1) show that until the $2^{\text {nd }}$ day when grafting (transfer of larvae into queen cups) was done, queen and worker larvae were in the same instar, $3^{\text {rd }}$ instar. One day after grafting the queen larvae was in the $4^{\text {th }}$ instar, while the worker larvae remained in the $3^{\text {rd }}$ instar. Five days after the grafting some of the queen larvae was still in the fifth instar but, most of the queen cups already contained pre-pupae and in the next day, pupae. In the brood comb, the worker larvae of the same age was in the $4^{\text {th }}$ instar ( 5 days after grafting) and $5^{\text {th }}$ instar ( 6 days after) according to the previous determination of Goitein (1989) for bees raised in the same conditions.

The results also show that the developmental rate of cephalic capsule (Fig. 1) from one instar to another is the same in queen and worker larvae. In spite of the same rate growth the gain in weight of worker and queen larvae is different. Queen larvae are already heavier than the workers one day after grafting, and the difference increases throughout the days (Fig. 2). Until three days after grafting there is little weight difference between worker and queen, but in the $5^{\text {th }}$ instar it is great. Queen larvae four days after grafting weighs twice as much as the worker and five days after two folds and a half. The queen and worker larvae duplicate its weight from the $4^{\text {th }}$ to the $5^{\text {th }}$ instar. 


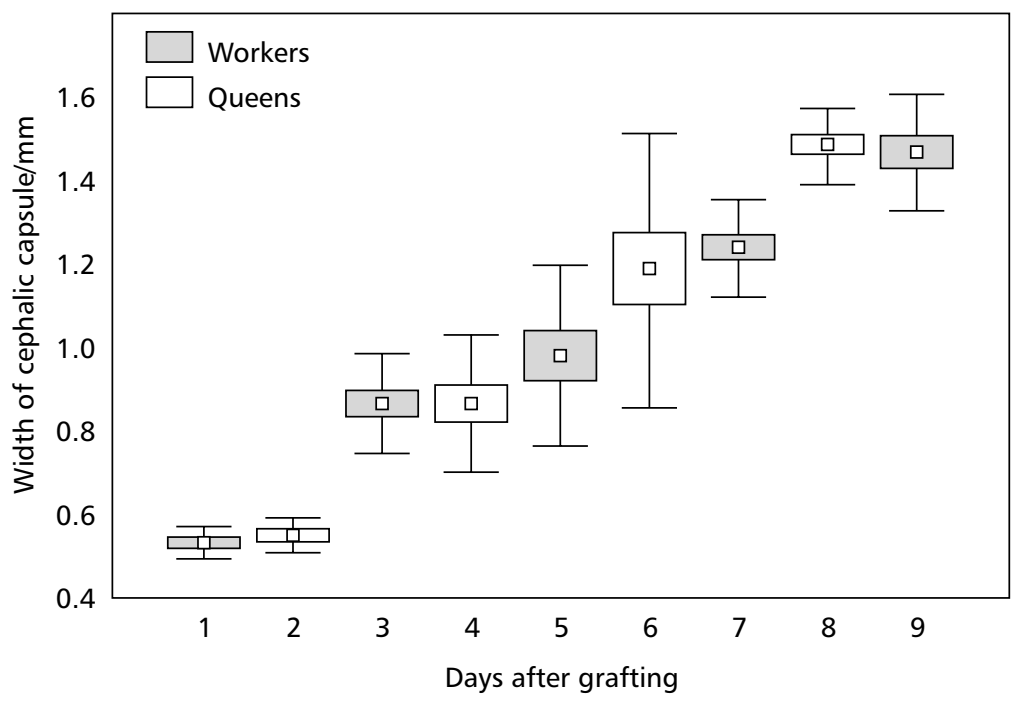

Fig. 1 - Cephalic capsule width of queen and worker of Apis mellifera larvae, from same queen laying battery 1, 3, 5, 7 and 9, worker larvae respectively 1, 2, 3, 4 and 5 days after some larvae of the batch have been graft, into queen cups. 2, 4,6 and 8 , queen larvae respectively 1,2,3,4 days after grafting.

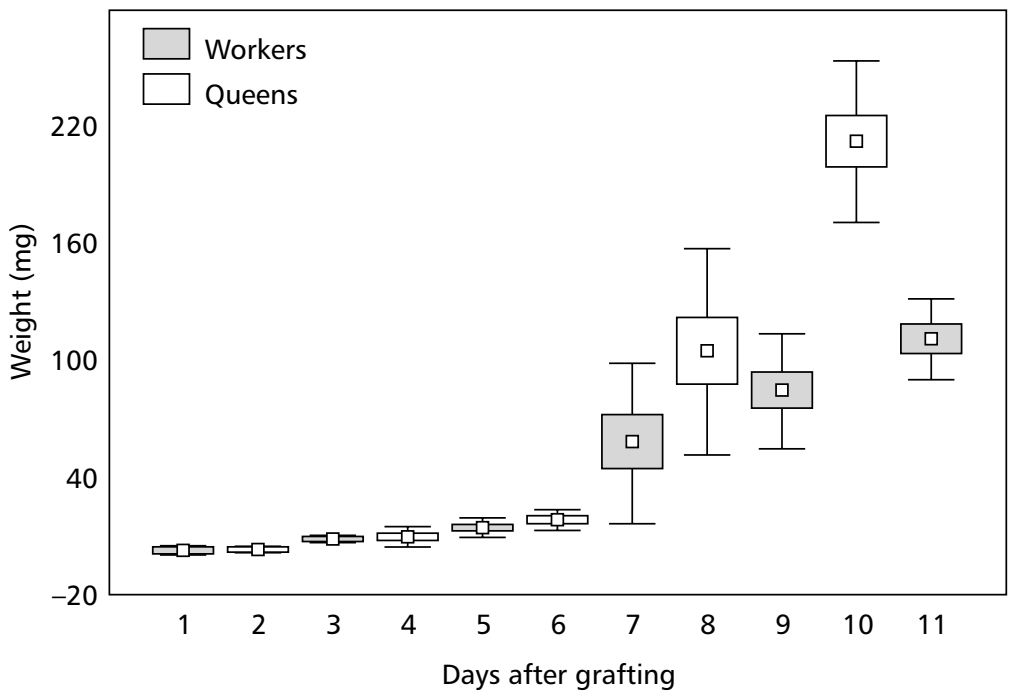

Fig. 2 - Average weight (mg) of queen and workers larvae of Apis mellifera during the development. 1, 3, 5, 7, 9 and 11, worker larvae respectively 1, 2, 3, 4, 5 and 6 days after some larvae of the same batch have been graft, into queen cups. $2,4,6,8$ and 10 , queen larvae respectively $1,2,3,4$ and 5 days after grafting. 
The ovaries have a continuous growth in both queen and worker during the larval development (Fig. 3), but the growth is greater in queen larvae mainly in the fifth instar. The queen larvae ovaries increase $15 \%$ from $2^{\text {nd }}$ to $3^{\text {rd }}$ instar, $78 \%$ from $3^{\text {rd }}$ to $4^{\text {th }}$ instar and $100 \%$ from $4^{\text {th }}$ to $5^{\text {th }}$ instar, while the worker larvae ovaries increase $10 \%$ from $2^{\text {nd }}$ to $3^{\text {rd }}$ instar, $63 \%$ from $3^{\text {rd }}$ to $4^{\text {th }}$ instar and from $4^{\text {th }}$ to $5^{\text {th }}$ instar it decreases. The queen ovaries continue to grow even after the fifth instar and during pupation (Fig. 3).

The examination of the ovary sections (Figs. 4-6) of queen and worker larvae on the $2^{\text {nd }}$ instar with light microscopy shows a mass of cells, where large cells are surrounded by small flat ones and the cell group by a capsule of several layers of flat cells (Fig. 4).

From these large cells seem to originate the germ cells, while the small surrounding cells give rise to the ovariole somatic tissue. As the ovarioles individualization advance they become separated one from another by inter-ovariolar flat cells, the stromatic cells, and their number becomes evident (Figs. 5 and 6).

At the $3^{\text {rd }}$ larval instar the morphology of the ovaries and the number of ovarioles seem the same in queen and worker larvae, but in workers, cell deaths may be observed in them. In the next stages $\left(4^{\text {th }}\right.$ and $5^{\text {th }}$ instars) differences in the ovariole numbers between queen and worker, can be observed. Nevertheless only by the end of the $5^{\text {th }}$ instar are they more evident and in pre pupae a great difference is established in the ovariole numbers between the two castes (Figs. 5 and 6).

The SEM examination (Figs. 7-15) show that after the $4^{\text {th }}$ instar the shape of workers and queens ovaries becomes different. The workers maintain the elongated form (Fig. 11) while in queens the ovaries round up (Figs. 12-14). Freeze-fracture of a queen $5^{\text {th }}$ instar ovary, shows a great number of ovarioles closely packed (Figs. 13 and 15). In pre-pupae the worker ovary has a cilindrical shape (Fig. 11) while the queen ovary has a roundflattened form (Fig. 14).

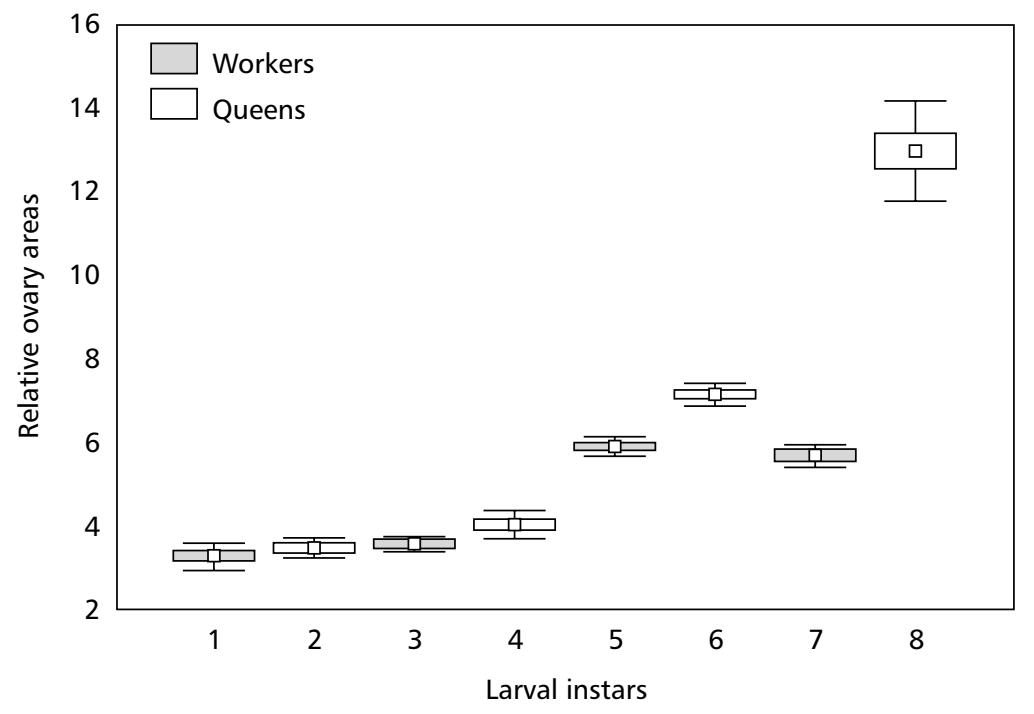

Fig. 3 - Relative average areas of worker and queen ovaries of Apis mellifera during larval development. 1, 3 and 5, 7 worker larvae respectively from $2^{\text {nd }}, 3^{\text {rd }}, 4^{\text {th }}$ and $5^{\text {th }}$ instar. $2,4,6$ and 8 queen larvae respectively from $2^{\text {nd }}, 3^{\text {rd }}, 4^{\text {th }}$ and $5^{\text {th }}$ instar. 

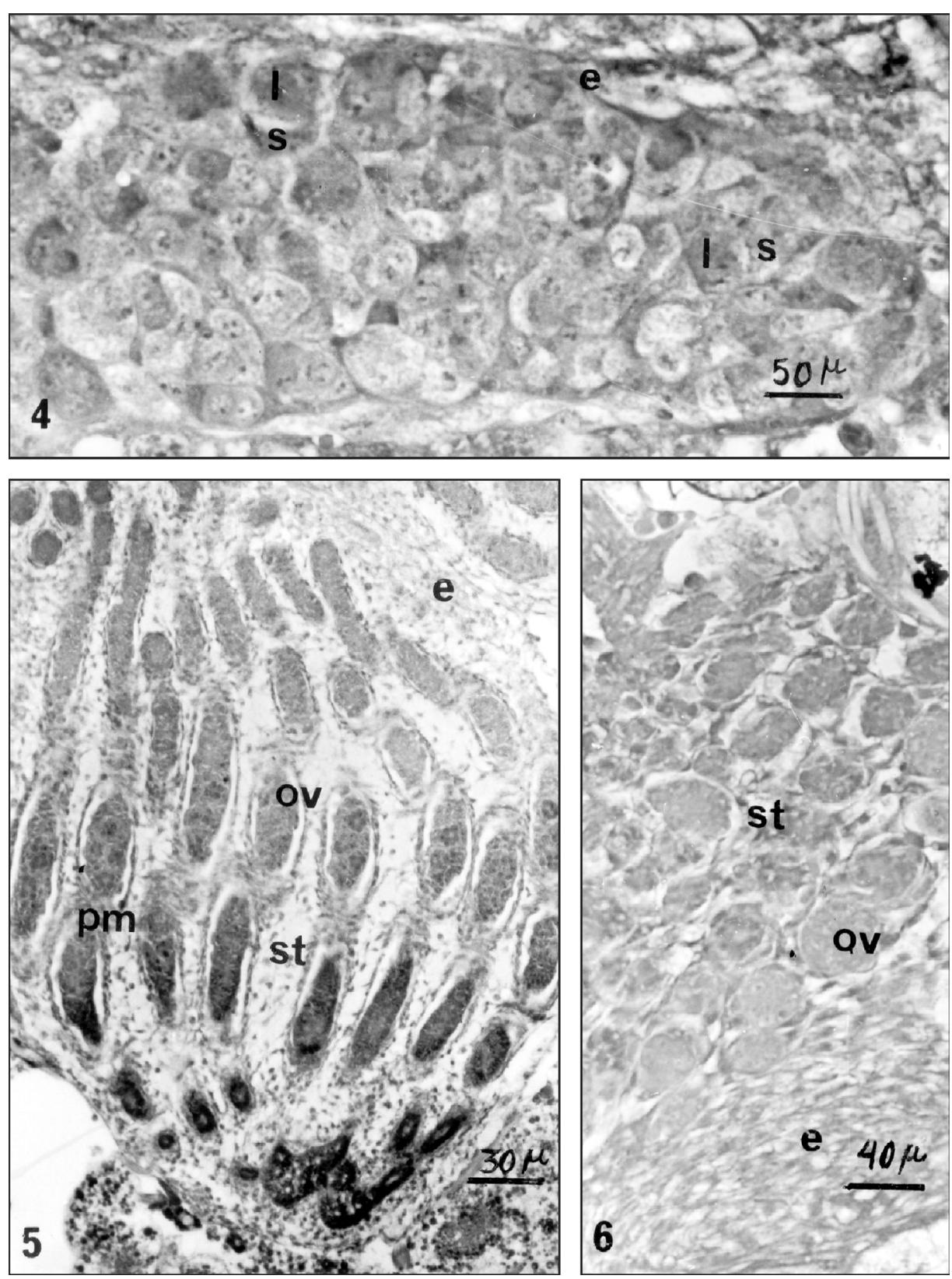

Figs. 4-6 - Light micrographies of Apis mellifera ovaries. Fig. 4 - Ovary of a $2^{\text {nd }}$ instar larva showing a mass of large round cells (1) probably germinative cells, surrounded by flat small cells (s). Fig. 5- Queen ovary of a $5^{\text {th }}$ instar larva showing the differentiated ovarioles (ov) separated by stromatic (st) cells. Fig. $6-$ Worker ovary of a $5^{\text {th }}$ instar larva, showing few ovarioles (ov). o = ovary capsule; $\mathrm{pm}=$ peritoneal membrane surrounding the ovariole. 

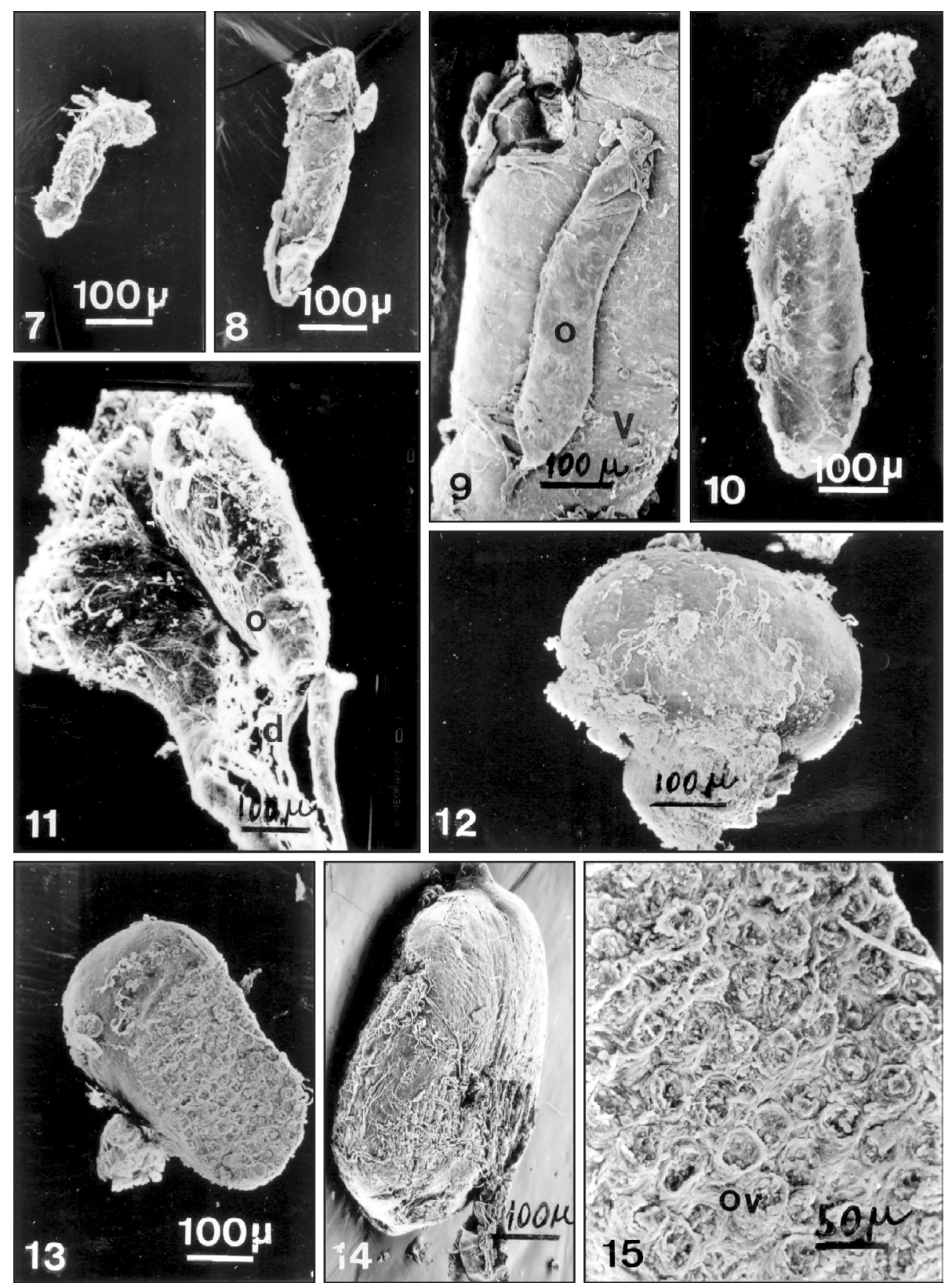

Figs. 7-15 - Scanning electron micrographs of the ovarian in different larval developmental phases. Figs. 7-11 - Worker ovaries: $7=2^{\text {nd }}$ instar; $8=3$ rd instar; $9=4^{\text {th }}$ instar, $10=5^{\text {th }}$ instar, $11=$ prepupa. Figs. 12-15 - Queen ovaries of larvae ending the $5^{\text {th }}$ instar. $12=$ outer view; $13=$ inner view showing the ovarioles, $14=$ ovary of a late $5^{\text {th }}$ instar larvae $15=$ cross section of the ovarioles. $\mathrm{o}=$ ovary; $\mathrm{v}=$ midgut ov $=$ ovarioles. 


\section{DISCUSSION}

Some authors (Lotmar, 1945; Beetsma, 1979) observed a difference in ovariole number in the ovaries of worker and queen larvae, starting with the differential feeding of the larvae, but others show that the ovaries from worker and queen larvae grow continuously during the larval phase (Meier, 1916; Bueno, 1981), without a great difference between them, suggesting that only by the end of the larval phase are the differences between the ovaries of queen and worker established (Bueno, 1981; Hartfelder \& Steinbrück, 1997).

These results seem conflicting but the present work shows that the differences in ovary size clearly starts once the feeding of the larvae becomes different. Reabsorption of ovarioles were seen by Reginato \& Cruz-Landim (2002) since the $3^{\text {rd }}$ instar in worker larvae and confirmed in this work. The ovariole reabsorption, however, does not totally reflect in the ovary size because the worker ovary continues to growth and stromatic cells fill up most of the space which before were occupied by the reabsorbed ovarioles, contributing to mantain the ovary total volume almost the same. Nevertheless, from the $4^{\text {th }}$ instar on, the number of ovarioles become much lower in workers and the size and shape of the ovaries in both castes started to change.

Aknowledgments — This study received financial support from FAPESP.

\section{REFERENCES}

ANGLAS, M. J., 1900, Observations sur les metamorphoses internes de la guêpe et de l'abeille. Bull. Biol. Fr. Belg., 34: $364-47$.

BEETSMA, J., 1979, The process of queen-worker differentiation in the honeybee. Bee Wld., 60: 24-39.

BUENO, O. C., 1981, Diferenciação dos ovários e determinação do número de ovaríolos em Apis mellifera $L$. (Hymenoptera, Apidae). Tese de Doutorado, USP, São Paulo, 59p.

CHAUD-NETTO, J. \& BUENO, O. C., 1979, Number of ovarioles in workers of Apis mellifera adansonii and Apis mellifera ligustica: a comparative study. J. Apicultural Res., 18: 260-263.
EVANS, J. D. \& WHEELER, D. E., 1999, Differential gene expression between developing queens and workers in the honey bee, Apis mellifera. Proceedings of the National Academy of Sciences of the USA, 96: 5575-5580.

GOITEIN, M. R. C., 1989, Estudos morfológicos $e$ morfométricos do corpo gorduroso e enócitos de Apis mellifera L. (Hymenoptera, Apidae) durante o desenvolvimento larval. Dissertação de Mestrado, Instituto de Biociências, Unesp, Rio Claro, SP, 77p.

HARTFELDER, K. \& STEINBRÜCK, G., 1997, Germ cell cluster formation and cell death are alternatives in castespecific differentiation of the larval honey bee ovary. Invert. Reprod. Develop, 31: 237-250.

HAYDAK, M. H., 1943, Larval food and the development of castes in honeybee. Jour. Econ. Ent., 36: 778-792.

KUWABARA, M., 1947, Ueber die Regulation in weisellosen Volke der Honigbiene besonders die Bestimung des neuen Weisels. Jour. Fac. Sci. Ser. VI Zool., 9: 359-381.

LOTMAR, R., 1945, Die metamorphose des Bienendarms (Apis mellifera). Beihefte Schweiz. Bienen-Zeitung, 1: 443506.

MEIER, K., 1916, Die postembryonale Entivicklung des Geschletsapparates der Arbeitsbiene (Apis mellifera L.). Z. angew. Ent., 3: 45-74.

MORINI, M. S. C. \& BUENO, O. C., 1995, Análise quantitativa dos ovários de rainhas de Apis mellifera caucasiana (Polm. 1889) (Hymenoptera, Apidae). Revta. Bras. Ent., 39: 403407 .

OERTEL, E., 1930, Metamorphosis in the honeybee. J. Morph. Physiol., 50: 295-340.

RACHINSKY, A., STRAMBI, C., STRAMBI, A. \& HARTFELDER, K., 1990, Caste and metamorphosis: hemolymph titers of juvenile hormone and ecdisteroids in last instar honeybee larvae. Gen. Comp. Endocr. 79: 31-38.

REGINATO, R. D. \& CRUZ-LANDIM, C., 2002, Morphological characterization of cell death during the ovary differentiation in worker honey bee. Cell Biology International, 26: 243-251.

REMBOLD, H., 1987, Caste differentiation of the honeybee: forteen years of biochemical research at Martinsried. In: J. Eder \& H. Rembold (eds.), Chemistry and biology of social insects. Verlag Peperny, Munchen, pp. 3-13.

RIBBANDS, C. R., 1953, The behaviour and social life of honeybees. Bee Research Ass., London, 352p.

SNODGRASS, R., 1956, Anatomy of honey bee. Comstock Publis. Ass., New York, 334p.

ZANDER, E. \& BECKER, F., 1925, Die Ausbilding des Geschlechts bei der Honigbiene. Erlanger Jb. Bienenk., 3: $163-223$. 